\title{
Efektivitas Antifungi Ekstrak Daun Patikan Kebo (Euphorbia hirta) Terhadap Jamur Penyebab Kandidiasis (Candida albicans)
}

\author{
Zulkarnain ${ }^{1}$, Cut Muthiadin'1, Fatmawati Nur¹, Rusmadi Rukmana1 \\ ${ }^{1}$ Jurusan Biologi Fakultas Sains dan Teknologi UIN Alauddin Makassar

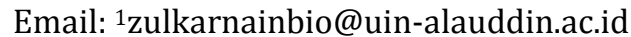

\begin{abstract}
Candidiasis is an infectious disease caused by the fungus Candida albicans. This study aims to determine the effect of patikan kebo (Euphorbia hirta) leaf extract in inhibiting the growth of C. albicans. This research is an experimental study which was compiled using a Completely Randomized Design (CRD) by giving Patikan Kebo (E. hirta) leaf extract in several concentrations, the concentrations of $40 \%, 45 \%, 50 \%$, 55\%, and $60 \%$ and controls (aquadest) and $C$. albicans mushroom with three repetitions. The parameters measured are the amount of inhibitory diameter formed around the paper discs in the 24 hour and 48 hour period. Data obtained with three repetitions and observations of 24 hours and 48 hours showed that giving patikan kebo leaf extract in several types of concentration had an effect on inhibiting the growth and fungi of C. albicans. Furthermore, the data obtained were analyzed using analysis of variance (F-test) at the level of $\alpha 0.05$ and continued using the Smallest Significant Difference (LSD) $\alpha 0.05$ where the results showed that the giving of patikan kebo extract significantly affected the microbial growth test (C. albicans), where the higher the concentration of patikan kebo leaf extract, the greater the inhibition zone formed around the paper disk.

Keywords: Candidiasis, patikan kebo (E. hirta) leaf extract, C. albicans
\end{abstract}

\section{Pendahuluan}

Indonesia merupakan negara yang kaya akan keanekeragaman hayati. Dimana Indonesia juga dikenal sebagai salah satu mega biodiversity country. Dari sekian banyak jumlah flora yang ada di Indonesia terdapat sekitar 30.000 jenis flora yang diduga diantaranya terdapat sekitar 9.600 spesies yang memiliki kemampuan berkhasiat obat. Dan jika lebih disederhanakan lagi dari jumlah tersebut tercatat 283 spesies merupakan tumbuhan obat penting bagi industri obat tradisional (Kusuma dan Zaky 2005).

Salah satu jenis spesies tumbuhan yang diketahui memiliki kemampuan berkhasiat obat adalah Patikan kebo (E. hirta), dimana tumbuhan ini merupakan tumbuhan liar yang banyak dengan mudahnya ditemukan di daerah tropis Indonesia. Tumbuhan ini biasanya tumbuh diantara rerumputan, tepi-tepi sungai dan pekarangan yang tidak terawat (Utami 2015).

Patikan kebo (E. hirta) berdasarkan struktur morfologinya merupakan tumbuhan berhabitus terna, yang tumbuhnya tegak atau seringkali memanjat, yang memiliki tinggi lebih kurang $20 \mathrm{~cm}$, permukaan batang yang berambut, dengan percabangan yang selalu keluar dan pangkal batang yang tumbuh ke atas, dengan warna batanng biasanya merah atau keunguan dan bergetah (Dalimartha 2008). Sedangkan dari segi kandungan fitokimianya pada Patikan kebo terkandung beberapa unsur, diantaranya terpenoid eufosterol alkaloid, tanin, flavonoid, asam organik palmitat oleat, asam lanolat, tarakseron, taraxerol, senyawa folifenol friedlin, betasitosterol, beta eufol, euforbol, tirukalol, eufosterol, hentriacontane, dan pada bunga terdapat alagic acid (Kusuma dan Zaky 
2005). Tanaman ini juga pada beberapa negaranegara di kawasan tropis telah banyak digunakan sebagai obat tradisional diantaranya Afrika, Australia, Amerika, dan Asia. Dimana patikan kebo tersebut telah dipercaya dapat menyembuhkan berbagai penyakit, seperti asma, disentri, demam, diare, borok, bronkhitis, penyakit pada alat genital (Handa et al. 2008).

Seiring perkembangan zaman terlihat bahwa jenis-jenis penyakit yang ada juga semakin beragam jenisnya, sehingga diperlukan berbagai macam jenis pengobatan terhadap suatu penyakit. Mulai dari pengobatan yang bersifat modern hingga pengobatan yang sifatnya tradisional yang kebanyakan menggunakan bahan-bahan alamiah, baik itu bersumber dari hewan maupun dari tumbuhan. Sehingga akhir-akhir ini banyak lembaga ilmiah penelitian dan perguruan tinggi mencurahkan perhatiannya terhadap tumbuhan-tumbuhan di Indonesia yang digunakan dalam rangka mendukung pengembangan pengobatan tradisional Indonesia (Achmad dan Hakim 2009). Salah satu jenis penyakit yang akhirakhir ini paling sering terjadi adalah penyakit infeksi oleh mikroorganisme. Infeksi adalah proses invasif oleh mikroorganisme berupa virus, bakteri, jamur, serta parasit yang selanjutnya berpoliferasi di dalam tubuh yang menyebabkan penyakit, yang mana tanpa disadari hidup kita sehari-hari tidak pernah luput dari incaran mikroorganisme yang tidak terlihat oleh mata telanjang (Besung 2009). Mikroorganisme tersebut berkeliaran di dekat kita. Beberapa jenis tidak berbahaya, namun beberapa jenis yang lain dapat mengancam kesehatan jika masuk ke dalam tubuh kita. Beberapa mikroorganisme secara umum menyebabkan penyakit manusia terutama hidup pada binatang dan secara tidak sengaja menginfeksi manusia. Misalnya kandidiasis.

Kandidiasis merupakan penyakit jamur yang bersifat akut yang menyerang mulut, vagina, kuku, dan rektum. Secara alamiah $C$. albicans yang merupakan jamur penyebab kandidiasis terdapat pada daerah-daerah tersebut, hanya saja jika pertumbuhannya pesat yang kemudian akan mengakibatkan peradangan yang disebut dengan kandidiasis. Salah satu jenis kandidiasis adalah kandidiasis kulit. Dimana jamur ini sering ditemukan di daerah lipatan, misalnya ketiak, di bawah payudara, lipat paha, lipat pantat dan sela jari kaki. Kulit yang terinfeksi tampak kemerahan, agak basah, bersisik halus dan berbatas tegas. Gejala utama adalah rasa gatal dan rasa nyeri bila terjadi maserasi atau infeksi sekunder oleh kuman (Darwis et al. 2012).

C. albicans dapat tumbuh dalam tiga bentuk, yaitu hifa, ragi, dan pesudohifa pada variasi $\mathrm{pH}$ yang luas, tetapi pertumbuhannya akan lebih baik pada pH antara 4,5-6,5. Jamur ini dapat tumbuh dalam perbenihan pada suhu $28^{\circ}$ C - $37^{\circ}$ C. C. albicans membutuhkan senyawa organik sebagai sumber karbon dan sumber energi untuk pertumbuhan dan proses metabolismenya. Unsur karbon ini dapat diperoleh dari karbohidrat (Sudbery et al. 2004). Berdasarkan uraian di atas, maka dilakukan penelitian dengan tujuan untuk mendapatkan konsentrasi yang efektif dari ekstrak Patikan kebo (E. hirta) dalam menghambat pertumbuhan jamur C. albicans penyebab kandidiasis.

\section{Metode}

\section{Instrumen Penelitian}

Alat-alat yang digunakan pada penelitian ini adalah cawan petri, inkubator, laminar air flow, ose bulat, neraca analitik, labu takar 100 $\mathrm{ml}$, tabung reaksi, gelas ukur, batang pengaduk, blender, oven, bunsen, jangka sorong, pelubang kertas, labu erlenmeyer, perlengkapan destilasi, bunsen spirtus, spoit, pinset, botol semprot, vortex, rak tabung, corong, gelas kimia dan kulkas.

Bahan-bahan yang digunakan pada penelitian ini adalah tumbuhan patikan kebo $(E$. hirta), C. albicans, aquadest, alumunium foil, kertas HVS, kertas saring, medium PDA (Potato Dekstrose Agar), pelarut etanol 96\%, spirtus, kapas penutup, tissue, dan alkohol 70\%.

Tahap Persiapan terdiri atas: 
a. Pembuatan medium PDA (Potato Dextrose Agar). Masing-masing bahan (kentang 200 gram, dekstrosa 7,5 gram, bacto agar 7,5 gram) ditimbang dengan teliti, lalu dilarutkan ke dalam aquadest $500 \mathrm{ml}$, kemudian dipanaskan sambil diaduk hingga homogen. Selanjutnya wadah ditutup dengan baik, kemudian disterilkan dalam otoklaf pada tekanan 2 atm, suhu 121oC selama 15 menit.

b. Sterilisasi Alat dan Bahan. Alat yang terbuat dari kawat platina seperti kawat ose, disterilkan dengan menggunakan bunsen dengan cara membakar alat tersebut di atas api sampai pijar, disamping itu juga digunakan dalam pengerjaan secara aseptis untuk menghindari terjadinya kontaminasi. Alat-alat yang tahan terhadap panas tinggi misalnya labu erlenmeyer, cawan petri, dan tabung reaksi, disterilkan dengan menggunakan oven biasanya pada suhu $180^{\circ} \mathrm{C}$, tetapi terlebih dahulu dicuci bersih dan disterilkan dengan menggunakan alkohol kemudian dibungkus dengan kertas.

Tahap pelaksanaan terdiri atas:

a. Pembuatan ekstrak patikan kebo (E. hirta). Daun patikan kebo (E. hirta) yang segar telah dibersihkan dengan menggunakan aquadest lalu diangin-anginkan selama 1 minggu hingga kering. Selanjutnya daun yang sudah kering diblender dan ditimbang sebanyak 200 gram kemudian dimaserasi dengan menggunakan etanol $800 \mathrm{ml}$ selama 24 jam. Kemudian disaring untuk memisahkan ampas dan larutan yang akan didestilasi. Selanjutya dilakukan destilasi selama \pm 2 jam dan hasilnya di simpan di gelas kimia serta ditutup dengan aluminium foil. Selanjutnya ekstrak yang diperoleh kemudian diencerkan sesuai dengan konsentrasi yang telah di tentukan. Adapun proses pengenceran adalah sebagai berikut: ekstrak patikan kebo (Euphorbia hirta) dipipet masing-masing sebanyak $4 \mathrm{ml}, 4,5$ $\mathrm{ml}, 5 \mathrm{ml}, 5,5 \mathrm{ml}$, dan $6 \mathrm{ml}$, kemudian disuspensikan dengan aquadest steril dalam $6 \mathrm{ml}, 5,5 \mathrm{ml}, 5 \mathrm{ml}, 4,5 \mathrm{ml}$, dan $4 \mathrm{ml}$ hingga diperoleh konsentrasi ekstrak masingmasing 40\%, $45 \%$, 50\%, 55\% dan 60\%. Adapun penentuan konsentrasi tersebut di atas didasarkan pada hasil uji pendahuluan sebelumnya

b. Peremajaan mikroba uji. Biakan Candida albicans diinokulasikan ke dalam medium PDA kemudian diinkubasi selama 24 jam dengan suhu $37^{\circ} \mathrm{C}$.

c. Pembuatan suspensi mikroba. Biakan Candida albicans yang telah diremajakan diambil dalam beberapa ose lalu diinokulasikan ke dalam $10 \mathrm{ml}$ aquadest steril kemudian digoyangkan hingga homogeny.

d. Pengujian daya hambat

1. Biakan C. albicans diikuti dengan penuangan medium PDA. Penuangan dilakukan apabila medium telah mencapai $\quad 45^{\circ} \mathrm{C}-50^{\circ} \mathrm{C} \quad$ kemudian dihomogenkan dengan cara cawan petri digoyang-goyangkan ke kiri dan ke kanan.

2. Paper disk yang telah dijenuhkan dengan aquadest sebagai kontrol dan larutan ekstrak daun patikan kebo ( $E$. hirta L) dengan konsentrasi 40\%, $45 \%$, 50\%, 55\% dan 60\% diletakkan secara aseptis pada cawan petri yang berisi medium PDA. Sampel pengujian diinkubasi pada suhu $37^{\circ} \mathrm{C}$ dalam inkubator selama 24 jam dan 48 jam.

e. Pengamatan dan pengolahan data Pengamatan dan pengolahan data dilakukan setelah masa inkubasi yang dilakukan selama 24 jam dan 48 jam pada suhu $37^{\circ} \mathrm{C}$ yaitu dengan melihat dan mengukur diameter zona hambatan yang terbentuk di sekeliling paper disk.

\section{Hasil dan Pembahasan}

Hasil pengamatan besarnya rata-rata diameter zona bening/hambat jamur C. albicans setelah diberikan beberapa macam konsentrasi ekstrak patikan kebo dengan tiga kali pengulangan ditunjukkan pada Tabel 1 dan 2 . Dimana hasil uji analisis statistik dengan 
Tabel 1. Rata-rata Diameter Zona Bening (hambatan) Pertumbuhan Jamur Candida albicans Oleh Ekstrak Daun Patikan Kebo Masa Inkubasi 24 Jam

\begin{tabular}{cccccc}
\hline \multirow{2}{*}{ Perlakuan } & \multicolumn{3}{c}{ Ulangan } & \multirow{2}{*}{ Jumlah } & $\begin{array}{c}\text { Rata-rata diameter } \\
\text { zona hambat }(\mathrm{mm})\end{array}$ \\
\cline { 2 - 4 } & I & II & III & & $0,00^{\mathrm{a}}$ \\
\hline A0 (kontrol) & 0 & 0 & 0 & 0 & $3,26^{\mathrm{b}}$ \\
A1D (40\%) & 4,1 & 3,2 & 2,5 & 9,8 & $3,73^{\mathrm{bc}}$ \\
A2D (45\%) & 4,2 & 4 & 3 & 11,2 & $4,60^{\mathrm{cd}}$ \\
A3D (50\%) & 5,6 & 4,7 & 3,5 & 13,8 & $5,40^{\mathrm{d}}$ \\
A4D (55\%) & 6 & 5,5 & 4,8 & 16,3 & $6,3 \mathrm{e}$ \\
A5D (60\%) & 7,3 & 6,1 & 5,5 & 18,9 & 23,29 \\
\hline \multirow{2}{*}{ Jumlah } & 27,2 & 23,5 & 19,3 & 70 & \\
\cline { 2 - 4 } & \multicolumn{5}{c}{ BNT $\alpha 0,05=1,43$} \\
\hline
\end{tabular}

Keterangan: Angka-angka yang diikuti oleh huruf yang sama, menunjukkan bahwa berbeda tidak nyata (5\%)

Tabel 2. Rata-rata Diameter Zona Bening (hambatan) Pertumbuhan Jamur Candida albicans Oleh Ekstrak Daun Patikan Kebo Masa Inkubasi 48 Jam

\begin{tabular}{cccccc}
\hline \multirow{2}{*}{ Perlakuan } & \multicolumn{3}{c}{ Ulangan } & \multirow{2}{*}{ Jumlah } & $\begin{array}{c}\text { Rata-rata diameter } \\
\text { zona hambat (mm) }\end{array}$ \\
\cline { 2 - 4 } & I & II & III & & $0,00^{\mathrm{a}}$ \\
A0 (kontrol) & 0 & 0 & 0 & 0 & $2,73^{\mathrm{b}}$ \\
A1D (40\%) & 3 & 2,8 & 2,4 & 8,2 & $2,96^{\mathrm{bc}}$ \\
A2D (45\%) & 3,1 & 2,9 & 2,9 & 8,9 & $3,23^{\text {cd }}$ \\
A3D (50\%) & 3,5 & 3,1 & 3,1 & 9,7 & $3,90^{\text {de }}$ \\
A4D (55\%) & 3,9 & 4 & 3,8 & 11,7 & $4,33^{\mathrm{e}}$ \\
A5D (60\%) & 4 & 4,3 & 4,7 & 13 & 17,16 \\
\hline \multirow{2}{*}{ Jumlah } & 17,5 & 17,1 & 16,9 & 51,5 & \\
\hline
\end{tabular}

Keterangan: Angka-angka yang diikuti oleh huruf yang sama, menunjukkan bahwa berbeda tidak nyata (5\%)

menggunakan uji F $\alpha$ 0,05 menunjukkan bahwa pemberian ekstrak patikan kebo dalam beberapa macam konsentrasi dengan tiga kali pengulangan berpengaruh nyata dalam menghambat pertumbuhan Jamur C. albicans melalui zona bening di sekeliling paper disk untuk pengamatan 24 jam dan 48 jam.

Hasil uji BNT $\alpha$ 0,05 menunjukkan bahwa pemberian ekstrak patikan kebo konsentrasi $40 \%$ berbeda nyata dengan kontrol dan demikian juga pada konsentrasi 45\%, 50\%, $55 \%$, dan $60 \%$, akan tetapi untuk konsentrasi $40 \%$ berbeda tidak nyata dengan konsentrasi $45 \%$, 50\% dan 55\%, hanya pada konsentrasi $60 \%$ yang berdeda nyata dengan konsentrasi lainnya. Sedangkan untuk uji BNT $\alpha 0,05$ inkubasi 48 jam menunjukkan bahwa pemberian ekstrak patikan kebo dengan konsentrasi $40 \%$ berbeda nyata dengan kontrol dan demikian juga pada konsentrasi 45\%, 50\%, $55 \%$, dan $60 \%$, akan tetapi untuk konsentrasi yang satu dengan konsentrasi lainnya berbeda tidak nyata. Rata-rata diameter zona bening pertumbuhan jamur $C$. albicans ditunjukkan pada Tabel 1 dan 2 .

Hasil yang diperoleh dari pengukuran rata-rata zona hambat diketahui bahwa pemberian ekstrak patikan kebo (E. hirta) juga dapat menghambat pertumbuhan $C$. albicans, hal ini dapat dilihat pada Tabel 1 dan 2. Dari hasil tersebut terjadi kenaikan rata-rata zona hambat di setiap konsentrasi yang terbentuk di sekeliling paper disk.

Hasil uji analisis statistik dengan menggunakan uji $F \quad \alpha \quad 0,05$ juga menunjukkan bahwa pemberian ekstrak patikan kebo dalam beberapa macam konsentrasi dengan tiga kali pengulangan berpengaruh nyata dalam 
menghambat pertumbuhan jamur C. albicans. Begitu juga dengan hasil uji BNT $\alpha$ 0,05 menunjukkan bahwa setiap perlakuan berbeda nyata dengan kontrol (Tabel 1).

Hal ini sesuai dengan teori yang mengatakan bahwa pada umumnya, kecepatan kematian mikroba berhubungan secara langsung dengan konsentrasi antimikroba. Ini berarti semakin tinggi konsentrasi antimikroba yang digunakan, semakin cepat mikroba tersebut terbunuh (Rstiati 2005). Salah satu senyawa yang terdapat pada patikan kebo yang bersifat sebagai antifungi adalah flavonoid, dimana flavonoid ini dapat bertindak sebagai antijamur karena mempunyai fenol yang dapat mendenaturasi protein dan dapat merusak membran sel yang bersifat irreversible (Sariningsih et al. 2015).

Mekanisme kerja fenol yaitu fenol dapat membentuk kompleks dengan ergosterol yang terdapat dalam membran sel jamur, kompleks tersebut menyebabkan pori-pori membesar pada sel jamur. Lewat pori-pori inilah komponen kecil dari isi sel jamur keluar seperti asam nukleat dan protein lainnya. Hal tersebut bila terus berlangsung akan menyebabkan kematian jamur (Rochani 2009). Kompleks fenol berada dalam keadaan lemah, disosiasi tidak langsung yang menyebabkan fenol menembus sel. Pada konsentrasi tinggi senyawa fenol dapat menyebabkan lisis pada sel membran. Fenol mempunyai kelarutan yang tinggi pada lipid, maka efek terbesar fenol adalah kemampuanya bergabung dengan komponen lipid sel. Membran sel pada jamur tersusun atas fosfolipid yang akan menyebabkan permeabilitas membran sel terganggu sehingga jamur terhambat (Wahyuningtyas 2008). Fenol apabila digunakan dalam konsentrasi tinggi, maka akan merusak membran sitoplasma secara total dan mengendapkan protein sel, yang mana dengan rusaknya membran sitoplasma akan menyebabkan bocornya metabolit penting dan disamping itu menginaktivkan sejumlah sistem enzim bakteri. Fenol efektif terhadap bentuk vegetatif bakteri dan kebanyakan fungi (Kumalasari dan Sulistyani (2011).
Hasil pengamatan pada Tabel 2 juga diketahui bahwa terjadi penurunan keefektifan antimikroba (antifungi) dari patikan kebo, dimana terjadi penurunan luas zona hambat dari masa inkubasi 24 jam ke 48 jam. Menurut Jawetz dalam istilah antifungi dikenal ada 2 pengertian yaitu fungisidal dan fungistatik (Melnick dan Adelberg 2005).

Fungisidal merupakan suatu senyawa yang mampu membunuh fungi sedangkan fungistatik adalah senyawa yang mampu menghambat pertumbuhan fungi tanpa membunuhnya (Minasari dan Dominika 2017). Sehingga dapat ditentukan sifat antimikroba (antifungi) dari ekstrak patikan kebo adalah sebagai fungistatik, yang berarti hanya mampu untuk menghambat pertumbuhan jamur $C$. albicans, dimana pada daerah atau zona hambatan yang terbentuk, secara perlahanlahan juga mulai ditumbuhi kembali oleh jamur tersebut. Sehingga sifat antimikroba (antifungi) dari patikan kebo ini tidak dapat digolongkan ke dalam fungisida karena tidak dapat membunuh. Adanya zona bening yang kembali ditumbuhi oleh jamur pada masa inkubasi 48 jam ini disebabkan oleh karena menurunnya keefektifan kerja dari senyawa-senyawa yang terdapat pada ekstrak patikan kebo tersebut, sehingga mikroba tersebut dapat tumbuh kembali pada daerah hambatan tersebut.

\section{Simpulan}

Ekstrak daun Patikan Kebo (E. hirta) berpengaruh dalam menghambat pertumbuhan C. albicans, dalam artian memiliki aktivitas sebagai antifungi. Hal ini terlihat pada hasil zona bening (daya hambat) yang ada pada setiap konsentrasi ekstrak patikan kebo. Semakin tinggi konsentrasi, maka semakin luas diamater zona bening yang terbentuk.

\section{Daftar Pustaka}

Achmad S. A, Hakim E. H. 2009. Ilmu Kimia dan Kegunaan Tumbuh-tumbuhan Obat Indonesia, 5th ed. Bandung: Penerbit ITB.

Besung I. N. K. 2009. Pegagan (Centella asiatica) sebagai alternative pencegahan infeksi 
pada ternak. J. Penelit. 1(2): 61-67.

Dalimartha S. 2008. Atlas Tumbuhan obat Indonesia, 5th ed. Jakarta: Pustaka Bunda.

Darwis W, Hafiedzani M, Astuti R. R. S. 2012. Efektivitas Ekstrak Akar dan Daun Pecut Kuda Stachytarpetha jamaicensis (L) Vahl Dalam Menghambat Pertumbuhan Jamur Candida albicans Penyebab Kandidiasis Vaginalis. Jurnal Ilmiah Konservasi Hayati. 8(2): 1-6.

Handa S. S, Khanuja S. P. S, Longo G, Rakesh D. D. 2008. Extraction Technologies for Medicinal and Aromatic Plants. Italia: ICSUNIDO.

Kumalasari E, Sulistyani N. 2011. Aktivitas antifungi batang binahong (Anredera cordifolia) terhadap Candida albicans serta skrining fitokimia. Jurnal Ilmiah Kefarmasian. 1(2): 51-62.

Kusuma F. R., Zaky B. M. 2005. Tumbuhan Liar Berkhasiat Obat. Jakarta: AgroMedia Pustaka.

Melnick J, Adelberg. 2005. Mikrobiologi Kedokteran. Jakarta: EGC-Penerbit Buku Kedokteran.

Minasari, Dominika D. 2017. Efek Fungistatis, Fungisidal Ekstrak Kayu Manis Terhadap
Candida albicans dan Efek Bakteristatis Staphylococcus aureus Dari Denture Stomatitis," J. Ilm. PANNMED 12(1): 1520.

Rstiati N. P. 2015. Pengantar Mikrobiologi Umum. Bali: Udayana University Press.

Rochani N. 2009. Uji Aktivitas Antijamur Ekstrak Daun Binahong (Anredera cordifolia) Terhadap Candida albicans Serta Skrining Fitokimianya. Universitas Muhammadiyah Surakarta.

Sariningsih P, Rita W. S, Puspawati N. M. 2015. Identifikasi dan Uji Aktivitas Senyawa Flavonoid dari Ekstrak Daun Trembesi (Samanea saman (Jacq.) Merr) sebagai Pengendali Jamur Fusarium sp. pada Tanaman Buah Naga. Jurnal Kimia. 9(1): 20-26.

Sudbery P, Gow N, Berman J. 2004. The distinct morphogenic states of Candida albicans. Trends Microbiol. 12(7): 317-324.

Utami P. 2015. Buku Pintar Tanaman Obat. Jakarta: AgroMedia Pustaka.

Wahyuningtyas E. 2008. Pengaruh Ekstrak Grapthophyllum Terhadap Pertumbuhan Candida albcans Pada Plat Gigi Tiruan Resin Akrilik. Indones. J. Dent., 15(3): 187191. 